Article

\title{
Copper Complexes of Nicotinic-Aromatic Carboxylic Acids as Superoxide Dismutase Mimetics
}

Thummaruk Suksrichavalit ${ }^{1}$, Supaluk Prachayasittikul ${ }^{2}$, Theeraphon Piacham ${ }^{1}$, Chartchalerm Isarankura-Na-Ayudhya ${ }^{1}$, Chanin Nantasenamat ${ }^{1}$ and Virapong Prachayasittikul ${ }^{1, *}$

1 Department of Clinical Microbiology, Faculty of Medical Technology, Mahidol University, Bangkok 10700, Thailand; E-mails: rukmu47@gmail.com (T. S.), mttpc@mahidol.ac.th (T. P.), mtcis@mahidol.ac.th (C. I.), mtcnt@mahidol.ac.th (C. N.), mtvpr@mahidol.ac.th (V.P.)

2 Department of Chemistry, Faculty of Science, Srinakharinwirot University, Bangkok 10110, Thailand; E-mail: supaluk@swu.ac.th (S. P.)

* Author to whom correspondence should be addressed; E-mail: mtvpr@mahidol.ac.th; Tel.: +66-2-418-0227; Fax: +66-2-412-4110.

Received: 25 September 2008; in revised form: 19 November 2008 / Accepted: 27 November 2008 / Published: 8 December 2008

\begin{abstract}
Nicotinic acid (also known as vitamin B3) is a dietary element essential for physiological and antihyperlipidemic functions. This study reports the synthesis of novel mixed ligand complexes of copper with nicotinic and other select carboxylic acids (phthalic, salicylic and anthranilic acids). The tested copper complexes exhibited superoxide dismutase (SOD) mimetic activity and antimicrobial activity against Bacillus subtilis ATCC 6633, with a minimum inhibition concentration of $256 \mu \mathrm{g} / \mathrm{mL}$. Copper complex of nicotinic-phthalic acids ( $\mathrm{CuNA} / \mathrm{Ph})$ was the most potent with a SOD mimetic activity of $\mathrm{IC}_{50} 34.42 \mu \mathrm{M}$. The SOD activities were observed to correlate well with the theoretical parameters as calculated using density functional theory (DFT) at the B3LYP/LANL2DZ level of theory. Interestingly, the SOD activity of the copper complex $\mathrm{CuNA} / \mathrm{Ph}$ was positively correlated with the electron affinity (EA) value. The two quantum chemical parameters, highest occupied molecular orbital (HOMO) and lowest unoccupied molecular orbital (LUMO), were shown to be appropriate for understanding the mechanism of the metal complexes as their calculated energies show good correlation with the SOD activity. Moreover, copper complex with the highest SOD activity were shown to
\end{abstract}


possess the lowest HOMO energy. These findings demonstrate a great potential for the development of value-added metallovitamin-based therapeutics.

Keywords: Nicotinic acid; Copper; Carboxylic acid; Superoxide dismutase; Antimicrobial activity.

\section{Introduction}

Nicotinic acid (NA) or vitamin B3 is essential for many biological processes namely for the production of energy [1], signal transduction, regulation of gene expression [2] and involvement in the synthetic pathway of lipids [3]. The oxidation of lipoproteins, low density lipoprotein and very low density lipoprotein, by free radical, particularly superoxide radical $\left(\mathrm{O}_{2}{ }^{-}\right)$, causes vascular inflammation, which is involved in the early stage development of atherosclerosis, a disease affecting arterial blood vessels [4]. In developed countries such as the United States, atherosclerosis is the leading cause of illness and death accounting for $44 \%$ of deaths and morbidity [5]. Nicotinic acid has been reported to decrease the production of free fatty acids and lipoproteins [6], despite of this free radical continues to appear in the human body. To eliminate such superoxide radicals, transition metal complexes were developed as superoxide dismutase mimics. Some examples include metalloporphyrin [7] and metal-drug complexes [8].

Complexation of nicotinic acid with various metals, e.g. manganese, cobalt, nickel, copper and zinc had been previously reported [9]. Nicotinic acid-copper complex (CuNA) has been shown to exert diverse bioactivities. In particular, it can stimulate blood flow and prevent gastric congestion [10], reduce total lipids in sera hepatic tissue as well as regulate levels of alanine transaminase, aspartate transaminase, alkaline phosphatase, gamma glutamyl transpeptidase and oxidative markers such as nitric oxide (NO) and lipid peroxidation in rat models [11]. Additionally, it also exhibits SOD mimic activity in patients with hepatocellular carcinoma. The metal complexes of nicotinic acid with other small molecules such as isonicotinate and acetylacetonate were previously reported [9, 12]. The aforementioned nicotinic acid-copper complexes were formed through coordination with the carboxylate oxygen- and/or pyridine nitrogen-atoms $[12,13]$, which are electron donors. These electron-donating groups are commonly found in many natural compounds such as flavonoids (rutin, taxifolin, epicatechin and luteolin), phenolics (catechol and resveratrol) and drugs (aspirin, ibuprofen and oxaprozin), all of which were reported to form metal complexes with potent superoxide scavenging capacities [14-16]. For example, flavonoid copper complexes were shown to exhibit higher SOD activity than the parent free flavonoids [15]. A series of simple $\mathrm{Cu}$ carboxylate (acetate, salicylate or benzoate) complexes synthesized by Devereux et al., were reported to exhibit excellent SOD mimic activity [17]. Salicylic acid, one of the metal-chelating ligands used in this study, is a natural compound found in most fruits and vegetables and functioning as a plant growth hormone. The compound was shown to possess promising anti-cancer activity by modulating the inhibition of the $\mathrm{P}$ form of phenolsulphotransferase, thus preventing excessive carcinogen activation [18]. Anthranilic acid (also known as vitamin L), another ligand used in the study, is a natural ingredient essential for lactation. Its derivatives have been found to activate soluble guanylyl cyclase, a ubiquitous NO 
receptor involved in vasorelaxation and hypertension [19]. In addition, copper atom is an essential nutrient involved in the catalytic function of many enzymes such as copper-zinc superoxide dismutase (CuZnSOD) [20, 21]. Copper deficiency has been reported to cause hematologic disorders, hypopigmentation, defective connective tissue cross-linking and ataxia [22, 23].

The ideal SOD-mimic should be a low molecular weight metal complex that possesses high membrane permeability. However, very few $\mathrm{Cu}$-carboxylate complexes had been reported [17]. In an attempt to obtain small molecule-based metal complexes, we now report the synthesis of novel copper complexes as potent SOD mimics. Such complexes are based on the coordination of nicotinic acid-Cu with the small molecule carboxylates phthalic acid $(\mathrm{Ph})$, salicylic acid (Sal) and anthranilic acid (Ant). Computational chemistry has found extensive applications for studying molecular structure and reactivity [24]. Some usage examples include studying the mechanism of protein receptor-inhibitor interaction [25], development of quantitative structure-activity/property relationship (QSAR/QSPR) [26], and elucidation of enzymatic reaction [27], etc. To shed light on the underlying mechanisms of the superoxide radical scavenging activities, quantum chemical parameters were calculated at DFT level. Results indicated that the calculated physicochemical parameters were well correlated with the experimental SOD activities. Such theoretical parameters included energies of HOMO and LUMO as well as EA. Furthermore, to confer value-added benefits to the copper complexes as well as explore the possibility of using such compounds as a multifaceted drug the antimicrobial activity of the novel complexes was also determined.

\section{Results and Discussion}

Three copper-based complexes, copper complexes of nicotinic-phthalic acids (CuNA/Ph, 1), nicotinic-salicylic acids (CuNA/Sal, 2) and nicotinic-anthranilic acids (CuNA/Ant, 3), were synthesized by the reaction of 1:1:1 ratio of cupric chloride with nicotinic acid and aromatic carboxylic acids (phthalic, salicylic and anthranilic acids). The complexes were obtained in excellent yields (8291\%) as aquamarine powder, highly polar, insoluble in methanol and water, but soluble in dimethyl sulfoxide (DMSO). Their melting points (m.p.) and magnetic moments $\left(\mu_{\text {eff }}\right)$ are listed in Table 1.

Table 1. Physicochemical parameters of nicotinic acid-copper complexes and ligands.

\begin{tabular}{|c|c|c|c|c|c|c|}
\hline Compound & $\begin{array}{l}\text { Chemical } \\
\text { Formula }\end{array}$ & $\begin{array}{c}\text { Formula } \\
\text { Weight } \\
\left(\mathrm{g} \cdot \mathrm{mol}^{-1}\right)\end{array}$ & Color & $\begin{array}{c}\text { Melting Point } \\
\left({ }^{\circ} \mathrm{C}\right)\end{array}$ & $\begin{array}{l}\text { Yield } \\
(\%)\end{array}$ & $\begin{array}{c}\mu_{\text {eff }} \\
\text { (B.M.) }\end{array}$ \\
\hline NA & $\mathrm{C}_{6} \mathrm{H}_{5} \mathrm{NO}_{2}$ & 123.11 & white & $236-239$ & - & - \\
\hline $\mathrm{Ph}$ & $\mathrm{C}_{8} \mathrm{H}_{6} \mathrm{O}_{4}$ & 166.13 & white & 210 & - & - \\
\hline $\mathrm{CuNA} / \mathrm{Ph}(\mathbf{1})$ & $\mathrm{C}_{14} \mathrm{H}_{10} \mathrm{CuNO}_{7}$ & 367.78 & aquamarine & $>300$ & 82 & 1.6944 \\
\hline Sal & $\mathrm{C}_{7} \mathrm{H}_{6} \mathrm{O}_{3}$ & 138.12 & white & $158-160$ & - & - \\
\hline CuNA/Sal (2) & $\mathrm{C}_{13} \mathrm{H}_{10} \mathrm{CuNO}_{6}$ & 339.77 & aquamarine & $>300$ & 85 & 1.6802 \\
\hline Ant & $\mathrm{C}_{7} \mathrm{H}_{7} \mathrm{NO}_{2}$ & 137.14 & yellow & $144-148$ & - & - \\
\hline CuNA/Ant (3) & $\mathrm{C}_{13} \mathrm{H}_{13} \mathrm{CuN}_{2} \mathrm{O}_{5}$ & 338.78 & aquamarine & $>300$ & 91 & 1.8038 \\
\hline
\end{tabular}




\section{Infrared spectra}

Coordination of the copper atom with the functional groups of the ligands was established from the IR spectra (Table 2). From the data of complex 1, it can be seen that the C-O stretching vibration frequency was located at $1,298 \mathrm{~cm}^{-1}$, while the free phthalic acid and nicotinic acid absorptions $v(\mathrm{C}-\mathrm{O})$ appeared at 1,282 and 1,299 $\mathrm{cm}^{-1}$, respectively. In addition, disappearance of the hydroxyl group bending vibration $(\delta \mathrm{O}-\mathrm{H})$ of $\mathrm{Ph}$ at $1,404 \mathrm{~cm}^{-1}$ was observed. For the carbonyl group $(\mathrm{C}=\mathrm{O})$, the stretching vibrations of both $\mathrm{NA}$ and $\mathrm{Ph}$ still exhibited intensive bands at 1,685, 1,701, and $1,718 \mathrm{~cm}^{-1}$. The weak band at $1333 \mathrm{~cm}^{-1}$ could be ascribed to C-N stretching vibration of complex $\mathbf{1}$ as compared with the spectra of NA, which shows strong band $v(\mathrm{C}-\mathrm{N})$ at $1324 \mathrm{~cm}^{-1}$. Thus, complex 1 was formed using pyridine ring nitrogen atom of NA and two hydroxyl groups of $\mathrm{Ph}$ to coordinate with copper atom. Structures of ligands are shown in Figure 1.

Table 2. IR spectra of the free ligands and the copper coordination complexes.

\begin{tabular}{|c|c|c|c|c|c|c|c|}
\hline Cpd & $v \mathbf{C}=\mathbf{O}$ & vC-O & $v \mathrm{C}-\mathrm{N}$ & vO-H & 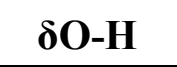 & vNH & $\delta \mathbf{N H}$ \\
\hline NA & $\begin{array}{l}1,718(\mathrm{~s}) \\
1,700(\mathrm{~s})\end{array}$ & $1,299(\mathrm{~s})$ & $1,324(\mathrm{~s})$ & $3,072-2,449(w)$ & $1,418(\mathrm{~s})$ & - & - \\
\hline $\mathrm{Ph}$ & $\begin{array}{l}1,700(\mathrm{~s}) \\
1,685(\mathrm{~s})\end{array}$ & $1,282(\mathrm{~s})$ & - & $3,072-2,524$ (br) & $1,404(\mathrm{~s})$ & - & - \\
\hline 1 & $\begin{array}{l}1,718(\mathrm{~s}) \\
1,701(\mathrm{~s}) \\
1,685(\mathrm{~s})\end{array}$ & $1,298(\mathrm{~m})$ & $1,333(\mathrm{w})$ & $3,080-2,565(w)$ & $1,418(\mathrm{~m})$ & - & - \\
\hline $\mathrm{Sal}$ & $\begin{array}{l}1,662(\mathrm{~s}) \\
1,655(\mathrm{~s})\end{array}$ & $\begin{array}{l}1,296(\mathrm{~s}) \\
1,250(\mathrm{~s}) \\
1,211(\mathrm{~s}) \\
1,156(\mathrm{~s})\end{array}$ & - & $\begin{array}{l}3,471 \text { (br) } \\
3,240 \text { (sh) }\end{array}$ & $\begin{array}{l}1,446(\mathrm{~s}) \\
1,484(\mathrm{~s})\end{array}$ & - & - \\
\hline 2 & $\begin{array}{l}1,717(\mathrm{~s}) \\
1,700(\mathrm{~s}) \\
1,685(\mathrm{~s})\end{array}$ & $\begin{array}{l}1,298(\mathrm{~s}) \\
1,201(\mathrm{w}) \\
1,144(\mathrm{w}) \\
1,126(\mathrm{w})\end{array}$ & $1,332(\mathrm{~m})$ & $\begin{array}{l}2,682(\mathrm{sh}, \mathrm{w}) \\
2,567(\mathrm{sh}, \mathrm{w})\end{array}$ & $\begin{array}{l}1,454(\mathrm{~m}) \\
1,420(\mathrm{~m})\end{array}$ & - & - \\
\hline Ant & $\begin{array}{c}1,679(\mathrm{~m}) \\
1,654(\mathrm{sh}, \mathrm{m})\end{array}$ & $\begin{array}{l}1,277(\mathrm{~m}) \\
1,238(\mathrm{~m})\end{array}$ & $\begin{array}{l}1,371(\mathrm{~s}) \\
1,319(\mathrm{~s})\end{array}$ & $\begin{array}{c}2,869(\mathrm{br}) \\
2,580(\mathrm{br}) \\
2,362(\mathrm{sh}, \mathrm{w}) \\
3,449(\mathrm{br})\end{array}$ & $1,458(\mathrm{~m})$ & $\begin{array}{l}3,325(\mathrm{sh}, \mathrm{s}) \\
3,239(\mathrm{sh}, \mathrm{s})\end{array}$ & 754 (vs) \\
\hline 3 & $\begin{array}{l}1,718(\mathrm{~s}) \\
1,700(\mathrm{~s})\end{array}$ & $1,298(\mathrm{~s})$ & $\begin{array}{l}1,386(\mathrm{~s}) \\
1,332(\mathrm{~m})\end{array}$ & $\begin{array}{l}3,400(\mathrm{br}) \\
2,681(\mathrm{w}) \\
2,565(\mathrm{w})\end{array}$ & $\begin{array}{l}1,458(\mathrm{~m}) \\
1,420(\mathrm{~m})\end{array}$ & $3,275(\mathrm{~m})$ & $756(\mathrm{~s})$ \\
\hline
\end{tabular}

Note: $\mathrm{vs}=$ very strong, $\mathrm{s}=$ strong, $\mathrm{m}=$ medium, $\mathrm{w}=$ weak, $\mathrm{br}=$ broad, $\mathrm{sh}=$ sharp.

In a similar fashion, the IR spectra of complex $\mathbf{2}$ were interpreted by comparison of its spectra with those of the free ligands. It was apparent that the hydroxyl and carbonyl absorptions of salicylic acid were at $3,471 \mathrm{~cm}^{-1} v(\mathrm{O}-\mathrm{H})$ and $1,655,1,662 \mathrm{~cm}^{-1} \mathrm{v}(\mathrm{C}=\mathrm{O})$, respectively, suggesting that Cu-complex 
formation took place via the phenolic and carbonyl functionalities. The IR spectra of complex 2 still displayed strong absorptions at 1,700,1,717 $\mathrm{cm}^{-1} v(\mathrm{C}=\mathrm{O}), 1,298 \mathrm{~cm}^{-1} v(\mathrm{C}-\mathrm{O})$ and $1,420 \mathrm{~cm}^{-1} \delta(\mathrm{O}-\mathrm{H})$. However, the C-N stretching vibration of complex 2 was observed at $1,332 \mathrm{~cm}^{-1}$ whereas the C-N absorption of free NA appeared at $1,324 \mathrm{~cm}^{-1}$. Based on the IR spectra, complex 2 was observed to be formed through the carbonyl and the phenolic hydroxyl group of Sal and the pyridine ring nitrogen atom.

Figure 1. Molecular structure of ligands: nicotinic acid (a), phthalic acid (b), salicylic acid (c), and anthranilic acid (d).<smiles>O=C(O)c1cccnc1</smiles>

(a)<smiles>O=C(O)c1ccccc1C(=O)O</smiles>

(b)<smiles>O=C(O)c1ccccc1O</smiles>

(c)<smiles>Nc1ccccc1C(=O)O</smiles>

(d)

The IR spectra of complex 3 exhibited disappearance of the anthranilic acid carbonyl $(\mathrm{C}=\mathrm{O})$ absorption at 1,654 and 1,679 $\mathrm{cm}^{-1}$. Additionally, the amino (NH) absorption of complex 3 appeared at $3,275 \mathrm{~cm}^{-1}$, while the $\mathrm{NH}_{2}$ absorption of Ant was observed at 3,239 and 3,325 $\mathrm{cm}^{-1}$. Strong C-N stretching of Ant was displayed at 1,371 and 1,319 $\mathrm{cm}^{-1}$ with a very strong $\mathrm{NH}$ bending observed at $754 \mathrm{~cm}^{-1}$. The IR spectra of complex 3 showed strong absorptions at 1,718, 1,700 (C=O), 1,298 (C-O), medium bending band of $\mathrm{OH}$ at $1,420 \mathrm{~cm}^{-1}$ and $\mathrm{C}-\mathrm{N}$ stretching of ring $\mathrm{N}$-atom at $1,332 \mathrm{~cm}^{-1}$. The characteristic free NA C-N stretching absorption of the pyridine ring $\left(v 1,324 \mathrm{~cm}^{-1}\right)$ was shifted to higher frequency at $1332 \mathrm{~cm}^{-1}$. The $\mathrm{C}-\mathrm{N}$ stretching of $\mathrm{NH}$ group of complex $\mathbf{3}$ was observed at 1,386 $\mathrm{cm}^{-1}$. It was suggested that complex 3 was formed through coordination of pyridine ring nitrogen atom; carbonyl and $\mathrm{NH}$ groups of Ant with $\mathrm{Cu}$ centered atom.

It is noted that these $\mathrm{Cu}$-complexes were formed via monodentate interaction of the ring nitrogen atom of NA resulting in a $v(\mathrm{C}-\mathrm{N})$ shift from $1,324 \mathrm{~cm}^{-1}$ to a higher frequency range of 1,332-1,333 $\mathrm{cm}^{-1}$. The $v(\mathrm{C}=\mathrm{O}), v(\mathrm{C}-\mathrm{O})$ and $\delta(\mathrm{O}-\mathrm{H})$ absorptions of the NA ligand of the complexes remained unperturbed. Aside from NA, other ligands coordinated with the central $\mathrm{Cu}$ atom via bidentate carboxylates. With regards to complex $\mathbf{1}, \mathrm{Ph}$ is the bidentate ligand using two hydroxyls of dicarboxylic acid to coordinate with the $\mathrm{Cu}$ atom. This is observed by the disappearance of $\mathrm{C}-\mathrm{O}$ stretching at 1,282 $\mathrm{cm}^{-1}$ and $\mathrm{O}-\mathrm{H}$ bending at $1,404 \mathrm{~cm}^{-1}$. As for complex 2, stretching at 1,662 and $1,655 \mathrm{~cm}^{-1}(\mathrm{C}=\mathrm{O})$ and at 3,471 and $3,240 \mathrm{~cm}^{-1}(\mathrm{O}-\mathrm{H})$ disappeared with a shift of $\mathrm{C}-\mathrm{O}$ stretching from $1,250,1,211$ and $1,156 \mathrm{~cm}^{-1}$ to lower frequencies. This suggested that the $\mathrm{Cu}$ atom formed a complex by means of a bidentate phenolic carboxylate. Similarly, the $\mathrm{Cu}$ atom of complex $\mathbf{3}$ was found to be coordinated with the amino carboxylate of Ant ligand, which is due to the disappearance of $\mathrm{C}=\mathrm{O}$ and $\mathrm{NH}_{2}$ stretching absorptions of Ant.

High resolution mass spectra (HRMS) measurements for complexes 1-3 were performed, but their molecular ions were not detected. Fragmented ions were observed at m/z of 124.0399 corresponding to 
free nicotinic acid as calculated for $\mathrm{C}_{6} \mathrm{H}_{5} \mathrm{NO}_{2}[\mathrm{M}+\mathrm{H}]^{+}$. Additionally, m/z of 124.0399 was quantified for complexes $\mathbf{1}$ and $\mathbf{2}$ while 124.0396 was detected for complex $\mathbf{3}$.

Complexes 1-3 were paramagnetic, with magnetic moments $\left(\mu_{\mathrm{eff}}\right)$ of 1.69, 1.68 and 1.80 B.M., respectively. The $\mu_{\text {eff }}$ value indicates that the complexes were of tetrahedral conformation with the $\mathrm{Cu}(\mathrm{II})$ center. Therefore, on the basis of both IR spectra and $\mu$ eff, we can confirm that complexes 1-3 were of tetrahedral geometry with the $\mathrm{Cu}(\mathrm{II})$ center.

\section{Superoxide scavenging activity}

The copper complexes were assayed for SOD-like activity using the modified method by measuring the inhibition of the photoreduction of nitro blue tetrazolium (NBT). The results showed that all the tested complexes exhibited SOD activities with $\mathrm{IC}_{50}$ in the range of $34.42-47.49 \mu \mathrm{M}$ as presented in Table 3.

Table 3. Superoxide dismutase activity of the free ligands and copper complexes.

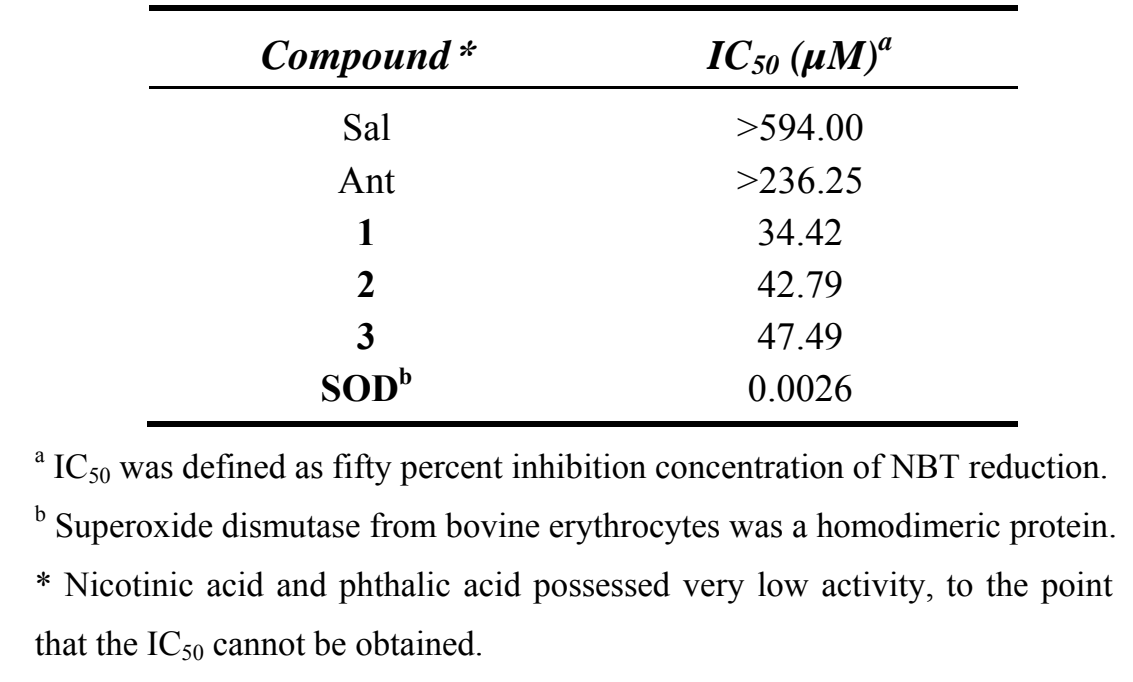

Complex 1 was the most potent SOD mimic with an $\mathrm{IC}_{50}$ of $34.42 \mu \mathrm{M}$. Moreover, the SOD activity of the free ligand, $\mathrm{NA}$ and $\mathrm{Ph}$, was very low to the point that the $\mathrm{IC}_{50}$ could not be obtained. The SOD activity of the uncoordinated salicylic and anthranilic acids was assayed and their $\mathrm{IC}_{50}$ was determined to be 594 and $236.25 \mu \mathrm{M}$, respectively. It was observed that complex 2 was approximately 14 times more potent than the uncoordinated Sal. Similarly, complex $\mathbf{3}$ was five times more potent than the free Ant. The results support the notion that the copper atom is essential for SOD activity and that the incorporation of copper into the structure of the ligands tremendously increased the SOD activity. We attribute this to the change in oxidation state of the copper atom modulated through its coordination with the metal-chelating ligands. It is noteworthy that the coordination complexes are much smaller than the native enzymes. Moreover, an added benefit is that the compounds can be easily synthesized from simple bioactive compounds. Some of the potent SOD mimics developed thus far were based on $\mathrm{Mn}$ and $\mathrm{Cu}$ coordination compounds. Example of such SOD mimics are the $\mathrm{Cu}$-drug complexes which included $\mathrm{Cu}$ (aspirin), $\mathrm{Cu}$ (aspirin) $)_{4}$ and $\mathrm{Cu}$ (ibuprofenate). 


\section{Antimicrobial activity}

Nicotinic acid is a widely used drug for the treatment of hyperlipidemia [3]. In addition, salicylic and anthranilic acids are bioactive aromatic carboxylic acids. The antimicrobial activity of complexes 1-3 has not been reported before. As the objective of this study is to develop value-added metallovitamins for therapeutic applications, therefore it is worthy to observe whether the compounds could also be used as antimicrobials, aside from being superoxide radical scavengers. Our results revealed that the tested complexes $\mathbf{1 - 3}$ can selectively inhibit the growth of $B$. subtilis ATCC 6633 with a MIC of $256 \mu \mathrm{g} / \mathrm{mL}$ (Table 4).

Table 4. Antimicrobial activity of the free ligands and nicotinic acid-copper complexes.

\begin{tabular}{|c|c|c|}
\hline Compound & Concentration $(\mu \mathrm{g} / \mathrm{mL})$ & Activity \\
\hline Ampicillin & 25 & Active $^{a}$ \\
\hline NA & 256 & Not Active \\
\hline \multirow[t]{2}{*}{$\mathrm{CuCl}_{2}$} & $64 *$ & Not Active \\
\hline & $32 *$ & Not Active \\
\hline $\mathrm{Ph}$ & 256 & Not Active \\
\hline \multirow[t]{3}{*}{1} & 256 & Active $^{\mathrm{b}}$ \\
\hline & 128 & Active $^{c}$ \\
\hline & 64 & Not Active \\
\hline Sal & 256 & Active $^{\mathrm{b}}$ \\
\hline \multirow[t]{3}{*}{2} & 256 & Active $^{b}$ \\
\hline & 128 & Active $^{\mathrm{d}}$ \\
\hline & 64 & Not Active \\
\hline Ant & 256 & Not Active \\
\hline \multirow[t]{3}{*}{3} & 256 & Active $^{b}$ \\
\hline & 128 & Active $^{c}$ \\
\hline & 64 & Not Active \\
\hline
\end{tabular}

${ }^{a}$ Active (100\% antigrowth) against $P$. aeruginosa ATCC 15442, S. putrefaciens ATCC 8671, A. xylosoxidans ATCC 2706, S. aureus ATCC 25923, S. epidermidis ATCC 12228, E. faecalis ATCC 29212, B. subtilis ATCC 6633, S. cereviseae ATCC 2601, S. pyogenes II, S. enteritidis type C, P. shigelloides, L. monocytogenes. Active against B. subtilis ATCC 6633 with ${ }^{\mathrm{b}} 100 \%$, ${ }^{\mathrm{c}}$ $50 \%,{ }^{\mathrm{d}} 25 \%$ antimicrobial activity. ${ }^{*} \mathrm{CuCl}_{2}$ was tested against B. subtilis ATCC 6633 .

It should be noted that salicylic acid was the only free ligand that could completely inhibit the growth of B. subtilis ATCC 6633 (MIC of $256 \mu \mathrm{g} / \mathrm{mL}$ ) and that the antimicrobial activity of salicylic acid and its derivatives against E. coli, B. subtilis and S. aureus has been previously reported [28]. Aside from this, the other free ligands (e.g. nicotinic, phthalic and anthranilic acids) were inactive against all of the tested microorganisms. A plausible explanation for the antimicrobial activity of the copper complexes is that they may enhance bacterial killing by synergistically converting superoxide radical to hydrogen peroxide in which accumulation of hydrogen peroxide exerted harmful effect to the bacterial cells as well as participated in the subsequent formation of hydroxyl radical via the Fenton's reaction. 


\section{Molecular modeling of SOD mimics}

To elucidate the mechanisms of radical scavenging activities of the copper complexes, density functional theory calculations at the B3LYP/LANL2DZ level was employed. Previous efforts have indicated that the calculation of theoretical parameters, binding energies and electron affinities, at such theoretical levels are suitable for characterizing the superoxide radical scavenging activity [29-32]. The molecular structures were constructed on the basis of IR and magnetic moment data which indicated that the coordination complex was of distorted tetrahedral conformation. Geometrically optimized structure of complexes 1-3 are presented in Figure 2.

Figure 2. Molecular structures of copper coordination complexes 1 (a), 2 (b), and 3 (c).

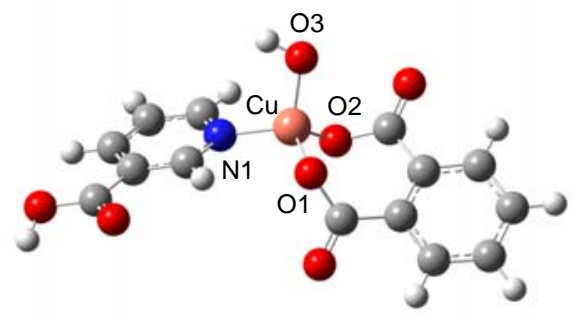

(a)

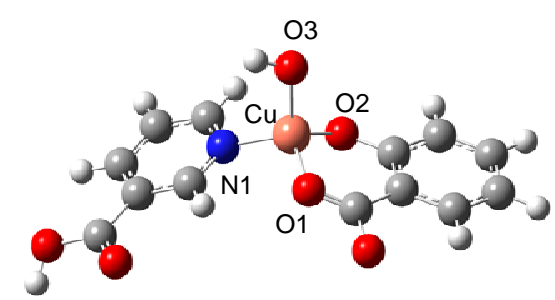

(b)

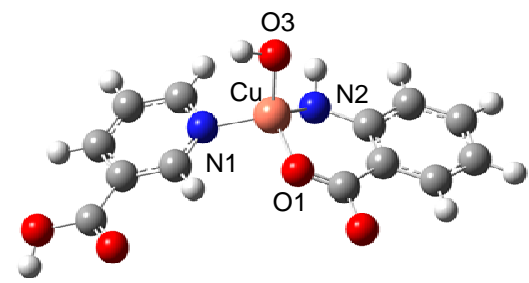

(c)

Electron affinity, in particular, is an appropriate theoretical parameter accounting for the electron transfer rate from superoxide anion to copper atom [30-32]. The lower the EA becomes the higher the electron transfer rate is, which correspondingly leads to higher superoxide radical scavenging activity. EA was calculated according to equation (1) by taking the difference of the total energy of $\mathrm{Cu}(\mathrm{II})$ and $\mathrm{Cu}(\mathrm{I})$ coordination complexes. The EA for complexes 1-3 as presented in Table 5 were calculated to be $-125.502,-139.283$ and $-212.679 \mathrm{kcal} / \mathrm{mol}$, respectively.

Table 5. Theoretical parameters of the copper complexes.

\begin{tabular}{cccc}
\hline Complex & $\begin{array}{c}\mathbf{T E}_{\mathbf{C u}(\mathrm{II})}{ }^{\mathbf{a}} \\
\text { (hartree) }\end{array}$ & $\begin{array}{c}\mathbf{T E}_{\mathbf{C u}(\mathrm{I})}{ }^{\mathbf{b}} \\
\text { (hartree) }\end{array}$ & $\begin{array}{c}\mathbf{E A}^{*} \\
\text { (kcal/mol) }\end{array}$ \\
\hline $\mathbf{1}$ & -1316.673 & -1316.873 & -125.502 \\
$\mathbf{2}$ & -1203.223 & -1203.445 & -139.283 \\
$\mathbf{3}$ & -1183.292 & -1183.631 & -212.679 \\
\hline
\end{tabular}

${ }^{\text {a }}$ Total energy of the $\mathrm{Cu}(\mathrm{II})$ coordination complex

${ }^{b}$ Total energy of the $\mathrm{Cu}(\mathrm{I})$ coordination complex

* EA was calculated according to equation (1) 
The experimental SOD activities of complexes 1-3 had an $\mathrm{IC}_{50}$ of $34.42,42.79$ and $47.49 \mu \mathrm{M}$, respectively. The results indicated that there exists a positive correlation between EA and SOD activity where high EA gives rise to high SOD activity, which is inversely correlated in previous reports [30, 31]. This is presumably due to differences in the coordination geometry of the copper complexes used in this study (tetragonally distorted) and the copper complexes (distorted square-planar and squarepyramidal) reported previously [30,31]. Similar observation was deduced by Branco et al. in their studies on active site distortion of CuZnSOD [33, 34].

Additionally, the usefulness of quantum chemical descriptors such as energy of the highest occupied molecular orbital and energy of the lowest unoccupied molecular orbital in elucidating the radical scavenging activity were also investigated. Examples on the usage of HOMO and LUMO energies in accounting for chemical reactivities of molecules and their relevance to electron transfer complexes can be found in an excellent review by Karelson and Lobanov [35]. The HOMO energies of the ligands were calculated to be $-5.818,-6.729$ and $-7.644 \mathrm{eV}$, respectively with the following order: Ant $>$ Sal $>$ Ph (Table 6).

Table 6. HOMO and LUMO energies of the free ligands and copper complexes.

\begin{tabular}{ccc}
\hline Compound & HOMO (eV) & LUMO (eV) \\
\hline Ph & -7.644 & -2.252 \\
Sal & -6.729 & -1.749 \\
Ant & -5.818 & -1.553 \\
$\mathbf{1}$ & -7.302 & -4.898 \\
$\mathbf{2}$ & -6.293 & -4.595 \\
$\mathbf{3}$ & -5.829 & -4.086 \\
\hline
\end{tabular}

Likewise, the calculated value of HOMO for the complexes exhibited similar trend: $\mathbf{3}>\mathbf{2}>\mathbf{1}$ with the corresponding values of $-5.829,-6.293$ and $-7.302 \mathrm{eV}$, respectively. It is well established that HOMO accounts for the electron donating ability while LUMO characterizes the ability to accept electron [36]. From the frontier molecular orbital approximation, high HOMO energy value infers that the molecule or ligand can easily release electrons to the unoccupied orbital of the metal ion, indicating strong binding affinity [37]. Thus, Ant possesses the strongest interaction with copper leading to the best binding capacity. Such degree of binding capacity is found to be Ant $>\mathrm{Sal}>\mathrm{Ph}$.

In addition, the selected bond lengths and angles of the geometrically optimized structures are given in Table 7. The average bond distance at axial position for $\mathrm{Cu}-\mathrm{N} 1$ of complexes 1-3 was $2.029 \AA$. The longest axial bond length for $\mathrm{Cu}-\mathrm{O} 1$ and $\mathrm{Cu}-\mathrm{O} 2$ were observed for complex 1 with values of 1.872 and $1.870 \AA$, respectively. The axial bond lengths of $\mathrm{Cu}-\mathrm{O} 1$ and $\mathrm{Cu}-\mathrm{O} 2$ for complex 2 was found to be shorter than that of complex 1 with values of 1.838 and $1.857 \AA$, respectively. This is explained by the inductive effect of the two carbonyl groups of complex 1 withdraws electrons from the $\mathrm{Cu}$ atom giving rise to low electron donating ability of the ligand as also indicated by the lower HOMO energy. Therefore, complex 1 exhibited the highest SOD activity. Finally, the shortest axial bond lengths for $\mathrm{Cu}-\mathrm{N} 2$ and $\mathrm{Cu}-\mathrm{O} 1$ were found in complex 3 to be 1.809 and $1.830 \AA$, respectively. This can be attributed to the greater electron donating ability of the amino group of anthranilic acid than the phenolic group of salicylic acid. This results in the lower HOMO energy of $\mathbf{2}$ than $\mathbf{3}$. It was previously 
reported by Li et al. [38] that axial bond lengths were crucial for SOD activity where long bond lengths being advantageous for the dismutation of superoxide anion. In addition, correlation between the binding capacity and the SOD activity of metal complexes was previously studied using molecular modeling and quantum chemical calculation [8]. It was found that molecules exhibiting higher metal binding affinity displayed lower SOD activity [8, 39]. This was observed for complex 3 which possessed the lowest SOD activity and the highest calculated HOMO value. On the other hand, complex 1 exhibited the highest SOD activity with the lowest calculated HOMO value (Tables 3 and 6). Furthermore, the calculated energies of HOMO and LUMO were well correlated with the SOD activity as observed from $r=0.999$ and 0.953 , respectively. Such results demonstrate the practical usage of HOMO and LUMO as theoretical parameters for the characterization of SOD activity in terms of charge- or electron-transfer of the complex.

Table 7. Selected bond distances $(\AA)$ and angles $\left(^{\circ}\right)$ of complexes 1-3.

\begin{tabular}{|c|c|c|c|c|}
\hline \multirow{2}{*}{$\frac{\text { Complex }}{1}$} & \multicolumn{2}{|c|}{ Bond Lengths ( $(\AA)$} & \multicolumn{2}{|c|}{ Angles $\left(^{\circ}\right)$} \\
\hline & $\mathrm{Cu}-\mathrm{N} 1$ & 2.035 & N1-Cu-O1 & 111.475 \\
\hline & $\mathrm{Cu}-\mathrm{O} 1$ & 1.872 & $\mathrm{~N} 1-\mathrm{Cu}-\mathrm{O} 2$ & 111.235 \\
\hline & $\mathrm{Cu}-\mathrm{O} 2$ & 1.870 & $\mathrm{~N} 1-\mathrm{Cu}-\mathrm{O} 3$ & 107.711 \\
\hline & $\mathrm{Cu}-\mathrm{O} 3$ & 1.829 & $\mathrm{O} 1-\mathrm{Cu}-\mathrm{O} 2$ & 105.661 \\
\hline & & & $\mathrm{O} 1-\mathrm{Cu}-\mathrm{O} 3$ & 110.275 \\
\hline & & & $\mathrm{O} 2-\mathrm{Cu}-\mathrm{O} 3$ & 110.513 \\
\hline \multirow[t]{6}{*}{2} & $\mathrm{Cu}-\mathrm{N} 1$ & 2.035 & $\mathrm{~N}(1)-\mathrm{Cu}-\mathrm{O} 1$ & 109.012 \\
\hline & $\mathrm{Cu}-\mathrm{O} 1$ & 1.838 & $\mathrm{~N}(1)-\mathrm{Cu}-\mathrm{O} 2$ & 111.596 \\
\hline & $\mathrm{Cu}-\mathrm{O} 2$ & 1.857 & $\mathrm{~N}(1)-\mathrm{Cu}-\mathrm{O} 3$ & 109.467 \\
\hline & $\mathrm{Cu}-\mathrm{O} 3$ & 1.836 & $\mathrm{O}(1)-\mathrm{Cu}-\mathrm{O} 2$ & 107.727 \\
\hline & & & $\mathrm{O}(1)-\mathrm{Cu}-\mathrm{O} 3$ & 109.929 \\
\hline & & & $\mathrm{O}(2)-\mathrm{Cu}-\mathrm{O} 3$ & 109.355 \\
\hline \multirow[t]{6}{*}{3} & $\mathrm{Cu}-\mathrm{N} 1$ & 2.016 & $\mathrm{~N} 1-\mathrm{Cu}-\mathrm{O} 1$ & 109.926 \\
\hline & $\mathrm{Cu}-\mathrm{N} 2$ & 1.809 & $\mathrm{~N} 1-\mathrm{Cu}-\mathrm{O} 2$ & 109.365 \\
\hline & $\mathrm{Cu}-\mathrm{O} 1$ & 1.830 & $\mathrm{~N} 1-\mathrm{Cu}-\mathrm{N} 2$ & 110.023 \\
\hline & $\mathrm{Cu}-\mathrm{O} 2$ & 1.835 & $\mathrm{~N} 2-\mathrm{Cu}-\mathrm{O} 2$ & 109.091 \\
\hline & & & $\mathrm{N} 2-\mathrm{Cu}-\mathrm{O} 1$ & 108.241 \\
\hline & & & $\mathrm{O} 1-\mathrm{Cu}-\mathrm{O} 2$ & 109.581 \\
\hline
\end{tabular}

\section{Conclusions}

The novel copper complexes with nicotinic acid and carboxylic acids were synthesized in excellent yields. The coordination compounds were characterized to be tetragonally distorted structures formed by monodentate coordination of ring $\mathrm{N}$-atom of NA as well as bidentate carboxylate ligands using amino carbonyl (Ant), phenolic carbonyl (Sal) and two hydroxyls ( $\mathrm{Ph}$ ). It should be noted that from the chemical and biological point of view, these copper complexes could easily be formed through the 
coordination of metal ions with simple dietary intake of vitamins or endogenous carboxylic acids and related compounds. All of the copper complexes were shown to exhibit superoxide scavenging activity as well as antimicrobial activities against B. subtilis ATCC 6633 with MIC $256 \mu \mathrm{g} / \mathrm{mL}$. Complex 1 was the most potent SOD activity with an $\mathrm{IC}_{50}$ of $34.42 \mu \mathrm{M}$. Theoretical parameters as calculated by DFT methods were used to elucidate the mechanisms of SOD activity. Interestingly, copper complexes with higher SOD activity such as complex 1 were found to have higher EA value. Furthermore, calculated HOMO and LUMO energies displayed good correlation with the SOD activities with $r$ of 0.999 and 0.953 , respectively. Such results corroborate the usefulness of HOMO and LUMO energies in relation to the SOD activity as it could account for the charge- or electron-transfer of the complex. These findings suggest great potential for the development of metallovitamin-based therapeutics.

\section{Experimental}

\section{General}

Melting points of the complexes were determined on the Griffin capillary melting point apparatus and are reported uncorrected. Infrared (IR) spectra were obtained on a Perkin Elmer System 2000 FTIR using potassium bromide $(\mathrm{KBr})$ pellet. Mass spectra were recorded on a Bruker Daltonics (MicroTOF) instrument. Magnetic moments were measured with a Mark 1 Magnetic Susceptibility Balance (Sherwood Scientific, Cambridge, UK). Nicotinic acid, phthalic acid, salicylic acid, and anthranilic acid were of analytical grade and purchased from Sigma-Aldrich, as was bovine erythrocyte superoxide dismutase.

\section{Synthesis of mixed-ligand complexes of copper with nicotinic acid and phtalic acid (1)}

Nicotinic acid $(0.123 \mathrm{~g}, 1 \mathrm{mmol})$ dissolved in methanol $(30 \mathrm{~mL})$ was heated $\left(70^{\circ} \mathrm{C}\right)$ and stirred under reflux until a clear solution was obtained. Cupric chloride dihydrate $(0.170 \mathrm{~g}, 1 \mathrm{mmol})$ dissolved in methanol $(2 \mathrm{~mL})$ and then added dropwise to the prepared nicotinic acid solution. After heating for $45 \mathrm{~min}$, the reaction mixture was added dropwise to a solution of phthalic acid ( $1 \mathrm{mmol}, 0.166 \mathrm{~g})$ in methanol $(2 \mathrm{~mL})$, then, the mixture was heated for $1 \mathrm{~h}$ under the same conditions. The precipitated solid was collected by filtration, washed with cold methanol and dried under vacuum over silica gel at room temperature. Complex 1 was obtained as an aquamarine powder; m.p. $>300^{\circ} \mathrm{C}$; $\mathrm{IR}\left(\mathrm{KBr}, \mathrm{cm}^{-1}\right)$ : 2,565-3,080 (m, OH), 1,685 (s, CO), 1,701 (s, CO), 1,718 (s, CO), 1,418 (m, OH), 1,333 (w, CN), 1,298 (m, C-O); HRMS (TOF) calculated for $\mathrm{C}_{6} \mathrm{H}_{5} \mathrm{NO}_{2}[\mathrm{M}+\mathrm{H}]^{+}$124.0399, found: 124.0399.

Synthesis of mixed-ligand complexes of copper with nicotinic acid and salicylic acid (2)

Complex 2 was prepared in the same way as complex 1 using nicotinic acid $(0.123 \mathrm{~g}, 1 \mathrm{mmol})$, cupric chloride $(0.170 \mathrm{~g}, 1 \mathrm{mmol})$ and $1 \mathrm{mmol}(0.138 \mathrm{~g})$ of salicylic acid. Product 2 was obtained as an aquamarine powder by filtration, washing with cold methanol and dried over silica gel; m.p. $>300^{\circ} \mathrm{C}$; IR $\left(\mathrm{KBr}, \mathrm{cm}^{-1}\right)$ : 2,567 (sh, w, OH), 2,682 (sh, w, OH), 1,717 (s, CO), 1,700 (s, CO), 1,685 (s, CO), 
1,454 (m, OH), 1,420 (m, OH), 1,332 (m, CN), 1,298 (s, C-O), 1,201 (w, C-O), 1,144 (w, C-O), 1,126 (w, C-O); HRMS (TOF) calculated for $\mathrm{C}_{6} \mathrm{H}_{5} \mathrm{NO}_{2}[\mathrm{M}+\mathrm{H}]^{+}$124.0399, found: 124.0399 .

Synthesis of mixed-ligand complexes of copper with nicotinic acid and anthranilic acid (3)

Complex 3 was prepared by an analogous procedure, but changing from $\mathrm{Ph}$ and/or Sal to anthranilic acid ( $1 \mathrm{mmol}, 0.137 \mathrm{~g})$ as a ligand. The precipitate of complex 3 was received as an aquamarine powder; m.p. $>300^{\circ} \mathrm{C}$; IR $\left(\mathrm{KBr}, \mathrm{cm}^{-1}\right)$ : 3,275 (m, NH), 3,400 (br, OH), 2,681 (w, OH), 2,565 (w, OH), 1,718 (s, CO), 1,700 (s, CO), 1,608 (s), 1,558 (vs), 1,458 (m, OH), 1,420 (m, OH), 1,386 (s, CN), $1,332(\mathrm{~m}, \mathrm{CN}), 1,298$ (s, C-O); HRMS (TOF) calculated for $\mathrm{C}_{6} \mathrm{H}_{5} \mathrm{NO}_{2}[\mathrm{M}+\mathrm{H}]^{+}$124.0399, found: 124.0396.

\section{Determination of superoxide dismutase (SOD)-like activity}

The complexes were tested for SOD activity using the previously described method [8]. The SOD activity of copper complexes was assayed by measuring the inhibition of the photoreduction of NBT. This indirect assay is comprised of several reactions: the photochemically excited riboflavin was first reduced by methionine to a semiquinone, which donated an electron to oxygen to form the superoxide source. The superoxide readily converted NBT into a purple formazan product, which was spectrophotometrically detected at $550 \mathrm{~nm}$. In this regard, the SOD activity was inversely related to the amount of formazan formed, and expressed in term of $\mathrm{IC}_{50}$ of NBT reduction.

\section{Antimicrobial activity}

The antimicrobial activity of the complexes was investigated against representative microorganisms using the method previously reported [40]. One milliliter of Müeller Hinton (MH) broth was mixed with the tested complexes dissolved in DMSO. The MH broth of the tested sample was then mixed with $\mathrm{MH}$ agar solution and placed onto the plates with the final concentrations $(64,128$ and 256 $\mu \mathrm{g} / \mathrm{mL}$ ) as agar dilution. The microorganisms, cultured in the $\mathrm{MH}$ broth at $37^{\circ} \mathrm{C}$ for $24 \mathrm{~h}$, were diluted with $0.9 \%$ normal saline solution to $3 \times 10^{8}$ cell $/ \mathrm{mL}$. The organisms were inoculated onto each plate and incubated at $37{ }^{\circ} \mathrm{C}$ for $18-48 \mathrm{~h}$. Complexes found to be effective against the tested strains were selected for further investigations. The inhibition of microbial cell growths was also determined. Twenty-seven strains of microorganisms were used as shown in Table 8.

\section{Molecular modeling of superoxide dismutase mimics}

The molecular models of the copper complexes were constructed with GaussView 3.09 [41] based on the IR and magnetic moment data which indicated that the coordination complexes were of distorted tetrahedral conformation. Full geometry optimizations without symmetry constraints were performed in vacuo using Becke's three-parameter hybrid Lee-Yang-Parr (B3LYP) [42] functional and the LANL2DZ [43-45] basis set under Gaussian 03W [46]. The LANL2DZ basis set was selected as it could handle high $\mathrm{Z}$ atoms [47], particularly atoms that are beyond the third row. 
Electron affinity was computed by taking the difference of the total energies of the coordination complexes $\mathrm{Cu}(\mathrm{II})$ and $\mathrm{Cu}(\mathrm{I})$ as summarized by the following equation:

$$
E A=T E_{C u(I)}-T E_{C u(I I)}
$$

where $E A$ represents the electron affinity, $T E_{C u(I)}$ represents the total energy of the $\mathrm{Cu}(\mathrm{I})$ coordination complex, $T E_{\mathrm{Cu}(\mathrm{II})}$ represents the total energy of the $\mathrm{Cu}(\mathrm{II})$ coordination complex. HOMO and LUMO energies were derived from geometrically optimized $\mathrm{Cu}(\mathrm{I})$ coordination complex as it is the active form of the SOD mimetics.

Table 8. Organisms subjected to growth inhibition assays.

\begin{tabular}{lll}
\hline Microorganism & \multicolumn{1}{c}{ Reference strain } & \multicolumn{1}{c}{ Clinical isolate } \\
\hline Gram-positive bacteria & Staphylococcus aureus ATCC 29213 & Streptococcus pyogenes II \\
& Staphylococcus aureus ATCC 25923 & Bacillus cereus \\
& Staphylococcus epidermidis ATCC 12228 & Listeria monocytogenes \\
& Enterococcus faecalis ATCC 29212 & \\
& Enterococcus faecalis ATCC 33186 & \\
& Micrococcus lutens ATCC 10240 & \\
& Bacillus subtilis ATCC 6633 & \\
& Corynebacterium diphtheriae NCTC 10356 & \\
Eram-negative bacteria & Escherichia coli ATCC 25922 & Shigella dysenteriae \\
& Klebsiella pneumoniae ATCC 700603 & Salmonella enteritidis type C \\
& Serratia marcescens ATCC 8100 & Morganella morganii \\
& Salmonella typhimurium ATCC 13311 & Aeromonas hydrophila \\
& Shewanella putrefaciens ATCC 8671 & Citrobacter freundii \\
& Achromobacter xylosoxidans ATCC 2706 & Plesiomonas shigelloides \\
& Pseudomonas aeruginosa ATCC 15442 & \\
& Pseudomonas stutzeri ATCC 17587 & \\
& Saccharomyces cereviseae ATCC 2601 & \\
Candida albicans ATCC 90028 & \\
\hline & & \\
\hline
\end{tabular}

\section{Acknowledgements}

We would like to thank the Faculty of Medical Technology, Mahidol University and the Faculty of Science, Srinakharinwirot University for facilities and supports as well as the Chulabhorn Research Institute for performing mass spectra measurements. T.S. is grateful for the graduate fellowship from The Ministry Staff Development Project by the Ministry of Education, Thailand. This project was also supported in part by the Young Scholars Research Fellowship from The Thailand Research Fund to T.P. (Grant No. MRG5080349) and C.N. (Grant No. MRG5080450) and the annual budget grant of Mahidol University (B.E. 2551-2555). 


\section{References}

1. Depeint, F.; Bruce, W.R.; Shangari, N.; Mehta, R.; O'Brien, P.J. Mitochondrial function and toxicity: role of the B vitamin family on mitochondrial energy metabolism. Chem. Biol. Interact. 2006, 163, 94-112.

2. Hageman, G.J.; Stierum, R.H. Niacin, poly(ADP-ribose) polymerase-1 and genomic stability. Mutat. Res. 2001, 475, 45-56.

3. Carlson, L.A. Nicotinic acid: the broad-spectrum lipid drug. A 50th anniversary review. J. Intern. Med. 2005, 258, 94-114.

4. Kamanna, V.S.; Kashyap, M.L. Mechanism of action of niacin. Am. J. Cardiol. 2008, 101, S20S26.

5. Gross, M., Lipids, Oxidation, and Cardiovascular Disease. In Atherosclerosis and Oxidant Stress. Holtzman, J.L., Ed. Springer: New York, 2008; 79-95.

6. Chapman, M.J. How does nicotinic acid modify the lipid profile? Eur. Heart. J. Suppl. 2006, 8, F54-59.

7. Spasojevic, I.; Chen, Y.; Noel, T.J.; Yu, Y.; Cole, M.P.; Zhang, L.; Zhao, Y.; St Clair, D.K.; Batinic-Haberle, I. Mn porphyrin-based superoxide dismutase (SOD) mimic, MnIIITE-2-PyP5+, targets mouse heart mitochondria. Free Radic. Biol. Med. 2007, 42, 1193-1200.

8. Piacham, T.; Isarankura-Na-Ayudhya, C.; Nantasenamat, C.; Yainoy, S.; Ye, L.; Bulow, L.; Prachayasittikul, V. Metalloantibiotic Mn(II)-bacitracin complex mimicking manganese superoxide dismutase. Biochem. Biophys. Res. Commun. 2006, 341, 925-930.

9. Singh, R.; Rao, R.S.S. Synthesis and characterization of divalent manganese, cobalt, nickel, copper and zinc complexes with nicotinic acid. J. Mol. Struct. 1981, 71, 23-30.

10. el-Saadani, M.A.; Nassar, A.Y.; Abou el-Ela, S.H.; Metwally, T.H.; Nafady, A.M. The protective effect of copper complexes against gastric mucosal ulcer in rats. Biochem. Pharmacol. 1993, 46, 1011-1018.

11. Salama, R.H.; Nassar, A.Y.; Nafady, A.A.; Mohamed, H.H. A novel therapeutic drug (copper nicotinic acid complex) for non-alcoholic fatty liver. Liver Int. 2007, 27, 454-464.

12. Huh, H.S.; Lee, S.W. Copper coordination polymers containing pyridinecarboxylate and multicarboxylate: $\left[\mathrm{Cu}_{1.5}(\mathrm{ina})(\mathrm{btcH})\right] \mathrm{H}_{2} \mathrm{O},\left[\mathrm{Cu}_{2}(\mathrm{ina})_{2}(\mathrm{bdc})_{0.5}\left(\mu_{3}-\mathrm{OH}\right)\right]$, and $[\mathrm{Cu}(\mathrm{ina})(\mathrm{na})](\mathrm{inaH}=4-$ pyridinecarboxylic acid, $\mathrm{btcH}_{3}=1,3,5$-benzenetricarboxylic acid, $\mathrm{bdcH}_{2}=1,3-$ benzenedicarboxylic acid, naH = 3-pyridinecarboxylic acid). J. Mol. Struct. 2007, 829, 44-50.

13. Yeh, C.-W.; Suen, M.-C.; Hu, H.-L.; Chen, J.-D.; Wang, J.-C. Synthesis and structural characterization of two new chiral coordination polymers of $\mathrm{Cu}(\text { nicotinate })_{2}\left(\mathrm{H}_{2} \mathrm{O}\right)$ and Co(nicotinate) $)_{2}$. Polyhedron 2004, 23, 1947-1952.

14. Dutta, S.; Padhye, S.; McKee, V. Structural characterization and SOD activity of copperoxaprozinate. Inorg. Chem. Commun. 2004, 7, 1071-1074.

15. Kostyuk, V.A.; Potapovich, A.I.; Strigunova, E.N.; Kostyuk, T.V.; Afanas'ev, I.B. Experimental evidence that flavonoid metal complexes may act as mimics of superoxide dismutase. Arch. Biochem. Biophys. 2004, 428, 204-208.

16. Mahal, H.S.; Kapoor, S.; Satpati, A.K.; Mukherjee, T. Radical scavenging and catalytic activity of metal-phenolic complexes. J. Phys. Chem. B 2005, 109, 24197-24202. 
17. Devereux, M.; O'Shea, D.; O'Connor, M.; Grehan, H.; Connor, G.; McCann, M.; Rosair, G.; Lyng, F.; Kellett, A.; Walsh, M.; Egan, D.; Thati, B. Synthesis, catalase, superoxide dismutase and antitumour activities of copper(II) carboxylate complexes incorporating benzimidazole, 1,10phenanthroline and bipyridine ligands: X-ray crystal structures of $\left[\mathrm{Cu}(\mathrm{BZA})_{2}(\mathrm{bipy})\left(\mathrm{H}_{2} \mathrm{O}\right)\right]$, $\left[\mathrm{Cu}(\mathrm{SalH})_{2}(\mathrm{BZDH})_{2}\right]$ and $\left[\mathrm{Cu}\left(\mathrm{CH}_{3} \mathrm{COO}\right)_{2}(5,6-\mathrm{DMBZDH})_{2}\right]\left(\mathrm{SalH}_{2}=\right.$ salicylic acid; BZAH = benzoic acid; BZDH = benzimidazole and 5,6-DMBZDH = 5,6-dimethylbenzimidazole). Polyhedron 2007, 26, 4073-4084.

18. Harris, R.M.; Hawker, R.J.; Langman, M.J.; Singh, S.; Waring, R.H. Inhibition of phenolsulphotransferase by salicylic acid: a possible mechanism by which aspirin may reduce carcinogenesis. Gut 1998, 42, 272-275.

19. Schindler, U.; Strobel, H.; Schonafinger, K.; Linz, W.; Lohn, M.; Martorana, P.A.; Rutten, H.; Schindler, P.W.; Busch, A.E.; Sohn, M.; Topfer, A.; Pistorius, A.; Jannek, C.; Mulsch, A. Biochemistry and pharmacology of novel anthranilic acid derivatives activating heme-oxidized soluble guanylyl cyclase. Mol. Pharmacol. 2006, 69, 1260-1268.

20. Bo, S.; Durazzo, M.; Gambino, R.; Berutti, C.; Milanesio, N.; Caropreso, A.; Gentile, L.; Cassader, M.; Cavallo-Perin, P.; Pagano, G. Associations of dietary and serum copper with inflammation, oxidative stress, and metabolic variables in adults. J. Nutr. 2008, 138, 305-310.

21. Olivares, M.; Uauy, R. Copper as an essential nutrient. Am. J. Clin. Nutr. 1996, 63, 791 S-796.

22. Koca, E.; Buyukasik, Y.; Cetiner, D.; Yilmaz, R.; Sayinalp, N.; Yasavul, U.; Uner, A. Copper deficiency with increased hematogones mimicking refractory anemia with excess blasts. Leuk. Res. 2008, 32, 495-499.

23. Twomey, P.J.; Reynolds, T.M.; Wierzbicki, A.S.; Viljoen, A. The relationship between serum copper and ceruloplasmin in routine clinical practice. Int. J. Clin. Pract. 2008, 62, 485-487.

24. Cramer, C.J. Essentials of Computational Chemistry: Theories and Models. 2nd ed.; John Wiley \& Sons, Ltd.: West Sussex, U.K., 2004.

25. Karawajczyk, A.; Drgan, V.; Medic, N.; Oboh, G.; Passamonti, S.; Novic, M. Properties of flavonoids influencing the binding to bilitranslocase investigated by neural network modelling. Biochem. Pharmacol. 2007, 73, 308-320.

26. Nantasenamat, C.; Isarankura-Na-Ayudhya, C.; Naenna, T.; Prachayasittikul, V. Prediction of bond dissociation enthalpy of antioxidant phenols by support vector machine. J. Mol. Graph. Model. 2008, 27, 188-196.

27. Cabelli, D.E.; Guan, Y.; Leveque, V.; Hearn, A.S.; Tainer, J.A.; Nick, H.S.; Silverman, D.N. Role of tryptophan 161 in catalysis by human manganese superoxide dismutase. Biochemistry 1999, 38, 11686-11692.

28. Han, P.; Chen, C.-Q.; Zhang, C.-L.; Song, K.-K.; Zhou, H.-T.; Chen, Q.-X. Inhibitory effects of 4chlorosalicylic acid on mushroom tyrosinase and its antimicrobial activities. Food Chem. 2008, 107, 797-803.

29. de Oliveira, G.; Martin, J.M.L.; de Proft, F.; Geerlings, P. Electron affinities of the first- and second-row atoms: Benchmark ab initio and density-functional calculations. Phys. Rev. A 1999, 60, 1034-1045.

30. Ji, H.F.; Zhang, H.Y. A theoretical study on $\mathrm{Cu}(\mathrm{II})$ binding modes and antioxidant activity of mammalian normal prion protein. Chem. Res. Toxicol. 2004, 17, 471-475. 
31. Ji, H.F.; Zhang, H.Y. A new strategy to combat Alzheimer's disease. Combining radicalscavenging potential with metal-protein-attenuating ability in one molecule. Bioorg. Med. Chem. Lett. 2005, 15, 21-24.

32. Shen, L.; Zhang, H.-Y.; Ji, H.-F. Computational note on the SOD-like antioxidant potential of nicotine-copper(II) complexes. J. Mol. Struct. (THEOCHEM) 2007, 817, 161-162.

33. Branco, R.J.F.; Fernandes, P.A.; Ramos, M.J. Density-functional calculations of the $\mathrm{Cu}, \mathrm{Zn}$ superoxide dismutase redox potential: The influence of active site distortion. J. Mol. Struct. (THEOCHEM) 2005, 729, 141-146.

34. Branco, R.J.F.; Fernandes, P.A.; Ramos, M.J. Cu, Zn Superoxide dismutase: distorted active site binds substrate without significant energetic cost. Theor. Chem. Acc. 2006, 115, 27-31.

35. Karelson, M.; Lobanov, V.S.; Katritzky, A.R. Quantum-chemical descriptors in QSAR/QSPR studies. Chem. Rev. 1996, 96, 1027-1044.

36. Guo, P.; Chen, W.; Song, J.; Cao, W.; Tian, C. A DFT study of the interaction between butein anion and metal cations $\left(\mathrm{M}=\mathrm{Mg}^{2+}, \mathrm{Cr}^{2+}, \mathrm{Fe}^{2+}\right.$, and $\left.\mathrm{Cu}^{2+}\right)$ : Taking an insight into its chelating property. J. Mol. Struct. (THEOCHEM) 2008, 849, 33-36.

37. Sun, R.; Ge, J.; Yao, J.; Li, S.; Shen, H.; Gu, R. Predicting the binding capability of benzothiazoline-2-thione and its derivatives with gold: A DFT and FT-Raman combined studies. Spectrochim. Acta A 2008, 71, 1535-1539.

38. Li, Q.X.; Luo, Q.H.; Li, Y.Z.; Shen, M.C. A study on the mimics of $\mathrm{Cu}-\mathrm{Zn}$ superoxide dismutase with high activity and stability: two copper(II) complexes of 1,4,7-triazacyclononane with benzimidazole groups. Dalton Trans. 2004, 2329-2335.

39. Garbutt, J.T.; Morehouse, A.L.; Hanson, A.M. Food additives, metal binding properties of bacitracin. J. Agr. Food Chem. 1961, 9, 285-289.

40. Prachayasittikul, S.; Suksrichavalit, T.; Isarankura-Na-Ayudhya, C.; Ruchirawat, S.; Prachayasittikul, V. Antimicrobial and antioxidative activities of 1-adamantylthio derivatives of 3-substituted pyridines. Excli J. 2008, 7, 63-70.

41. Dennington II, R.; Keith, T.; Millam, J.; Eppinnett, K.; Hovell, W.L.; Gilliland, R. GaussView, version 3.09; Semichem, Inc.: Shawnee Mission, KS, 2003.

42. Stephens, P.J.; Devlin, F.J.; Chabalowski, C.F.; Frisch, M.J. Ab initio calculation of vibrational absorption and circular dichroism spectra using density functional force fields. J. Phys. Chem. 1994, 98, 11623-11627.

43. Hay, P.J.; Wadt, W.R. Ab initio effective core potentials for molecular calculations. Potentials for the transition metal atoms Sc to Hg. J. Chem. Phys. 1985, 82, 270-283.

44. Hay, P.J.; Wadt, W.R. Ab initio effective core potentials for molecular calculations. Potentials for $\mathrm{K}$ to $\mathrm{Au}$ including the outermost core orbitals. J. Chem. Phys. 1985, 82, 299-310.

45. Wadt, W.R.; Hay, P.J. Ab initio effective core potentials for molecular calculations. Potentials for main group elements Na to Bi. J. Chem. Phys. 1985, 82, 284-298.

46. Frisch, M.J.; Trucks, G.W.; Schlegel, H.B.; Scuseria, G.E.; Robb, M.A.; Cheeseman, J.R.; Montgomery, J., J. A.; Vreven, T.; Kudin, K.N.; Burant, J.C.; Millam, J.M.; Iyengar, S.S.; Tomasi, J.; Barone, V.; Mennucci, B.; Cossi, M.; Scalmani, G.; Rega, N.; Petersson, G.A.; Nakatsuji, H.; Hada, M.; Ehara, M.; Toyota, K.; Fukuda, R.; Hasegawa, J.; Ishida, M.; Nakajima, T.; Honda, Y.; Kitao, O.; Nakai, H.; Klene, M.; Li, X.; Knox, J.E.; Hratchian, H.P.; Cross, J.B.; 
Bakken, V.; Adamo, C.; Jaramillo, J.; Gomperts, R.; Stratmann, R.E.; Yazyev, O.; Austin, A.J.; Cammi, R.; Pomelli, C.; Ochterski, J.W.; Ayala, P.Y.; Morokuma, K.; Voth, G.A.; Salvador, P.; Dannenberg, J.J.; Zakrzewski, V.G.; Dapprich, S.; Daniels, A.D.; Strain, M.C.; Farkas, O.; Malick, D.K.; Rabuck, A.D.; Raghavachari, K.; Foresman, J.B.; Ortiz, J.V.; Cui, Q.; Baboul, A.G.; Clifford, S.; Cioslowski, J.; Stefanov, B.B.; Liu, G.; Liashenko, A.; Piskorz, P.; Komaromi, I.; Martin, R.L.; Fox, D.J.; Keith, T.; Al-Laham, M.A.; Peng, C.Y.; Nanayakkara, A.; Challacombe, M.; Gill, P.M.W.; Johnson, B.; Chen, W.; Wong, M.W.; Gonzalez, C.; Pople, J.A. In Gaussian 03, Revision C.02, Gaussian, Inc.: Wallingford CT, 2004.

47. Foresman, J.B.; Frisch, A. Exploring Chemistry with Electronic Structure Methods. Gaussian, Inc.: Pittsburgh, 2000.

Sample Availability: Contact authors.

(C) 2008 by the authors; licensee Molecular Diversity Preservation International, Basel, Switzerland. This article is an open-access article distributed under the terms and conditions of the Creative Commons Attribution license (http://creativecommons.org/licenses/by/3.0/) 